\title{
Universiteit
}

Leiden

The Netherlands

\section{Guerrillawinkels, het SoCo Experiment en een volgende Big Bang : over de rol van nieuwe media en de toekomst van journalistiek in een vloeibare samenleving}

Deuze, Mark

\section{Citation}

Deuze, M. (2008). Guerrillawinkels, het SoCo Experiment en een volgende Big Bang : over de rol van nieuwe media en de toekomst van journalistiek in een vloeibare samenleving. Leiden University Press. Retrieved from https://hdl.handle.net/1887/21149

Version: $\quad$ Not Applicable (or Unknown)

License: $\quad$ Leiden University Non-exclusive license

Downloaded from: $\quad$ https://hdl.handle.net/1887/21149

Note: To cite this publication please use the final published version (if applicable). 


\section{Guerrillawinkels,}

het SoCo Experiment

en een volgende

Big Bang

Over de rol van nieuwe media en de toekomst van journalistiek in een vloeibare samenleving

Mark Deuze

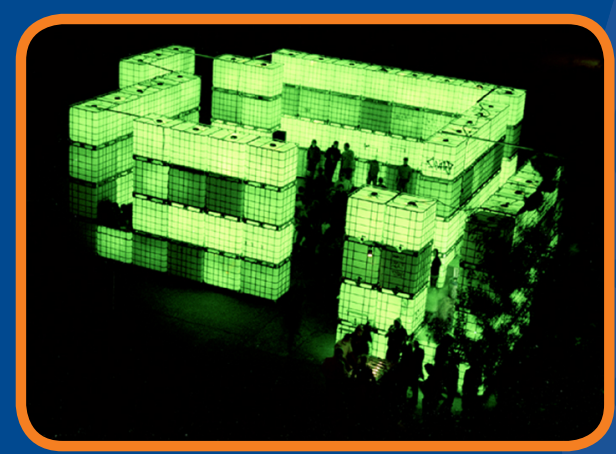

LUP ORATIES 


\section{Guerrillawinkels, het SoCo Experiment en een volgende Big Bang}





\title{
Guerrillawinkels, het SoCo Experiment en een volgende Big Bang
}

Over de rol van nieuwe media en de toekomst van journalistiek in een vloeibare samenleving

\author{
Rede
}

uitgesproken bij de aanvaarding van het ambt van

hoogleraar in de Journalistiek en Nieuwe Media

aan de Universiteit Leiden

op vrijdag 18 januari 2008

door

Mark Deuze 
Afbeelding omslag: Kubik-club in Barcelona.

Omslagontwerp: Randy Lemaire, Utrecht

Zetwerk: JAPES, Amsterdam

ISBN 9789087280352

NUR 813

(C) Leiden University Press, Amsterdam, 2008

Leiden University Press is een imprint van Amsterdam University Press

Alle rechten voorbehouden. Niets uit deze uitgave mag worden verveelvoudigd, opgeslagen in een geautomatiseerd gegevensbestand, of openbaar gemaakt, in enige vorm of op enige wijze, hetzij elektronisch, mechanisch, door fotokopieën, opnamen of enige andere manier, zonder voorafgaande schriftelijke toestemming van de uitgever.

Voorzover het maken van kopieën uit deze uitgave is toegestaan op grond van artikel $16 \mathrm{~B} \mathrm{Au-}$ teurswet $1912 \mathrm{j}^{\circ}$ het Besluit van 20 juni 1974, Stb. 351, zoals gewijzigd bij het Besluit van 23 augustus 1985 , Stb. 471 en artikel 17 Auteurswet 1912, dient men de daarvoor wettelijk verschuldigde vergoedingen te voldoen aan de Stichting Reprorecht (Postbus 3051, 2130 KB Hoofddorp). Voor het overnemen van gedeelte(n) uit deze uitgave in bloemlezingen, readers en andere compilatiewerken (artikel 16 Auteurswet 1912) dient men zich tot de uitgever te wenden. 
Mijnheer de Rector Magnificus, Zeer gewaardeerde toehoorders,

Het is tegenwoordig zo'n gedoe om eens lekker een avondje te gaan stappen. Tegen de tijd dat je je uitgaanskleren aanhebt, een taxi of ander vervoer is geregeld, je eindeloos buiten in de rij hebt gestaan om binnen te komen en je zwaar verdiende euro's hebt zien verdwijnen in de grijpgrage handen van portiers, garderobepersoneel en barkeepers heb je er al geen zin meer in. Het zou zoveel handiger zijn als de nachtclub naar je toekomt. Hetzelfde geldt voor een avondje bioscoop: waarom kan dat niet om de hoek, zonder dat je daarvoor naar de overvolle en overprijsde binnenstad toe moet? Om maar niet te spreken over de file naar het winkelcentrum of het gezwoeg op zoek naar een fatsoenlijk onderkomen op weg naar een verre vakantieplaats. Geen nood. Tegenwoordig komen discotheken, filmtheaters, winkels en hotels gewoon naar je toe.

Zo is daar het SoCo Cargo Experiment, bedacht door het Australische adviesbureau Herrmann International in opdracht van de Amerikaanse Southern Comfort Company - producent van het gelijknamige whiskylikeurtje. ${ }^{1}$ In een poging het ietwat suffe merkimago van Southern Comfort op te poetsen, bedacht men een nieuwe naam - SoCo - en een uiterst hippe en aan de tijdsgeest aangepaste marketingstrategie. Het SoCo Cargo Experiment bestaat uit een aantal twaalf meter lange schipcontainers die voor een aantal dagen ergens in de buurt van een grote stad op een strand worden gedumpt. Aan de buitenkant zijn het doodgewone, licht gehavende containers, maar aan de binnenkant wordt de argeloze bezoeker getrakteerd op een hele serie speelse 'ervaringen': een hippe loungebar, een miniconcertzaal en een postmoderne kunstgalerij. Zodra de lol er weer af is, de vergunning verloopt of de publiciteit afneemt, kan het hele boeltje razendsnel worden opgedoekt en verplaatst naar een locatie elders in het land.

Een vergelijkbare visie op tijdelijke architectuur komt van de Duitse ontwerpers Modularbeat in de vorm van Kubik. ${ }^{2}$ Een Kubik is een door allerlei 'gezellige' drankmerken gesponsorde discotheek bestaande uit tientallen gestapelde watertanks, uitgerust met trendy belichting en dito geluidsinstallatie. Deze Kubik-clubs 
duiken de laatste jaren op in Europese hoofdsteden, waar ze overigens na enkele weken feestgedruis weer rap verdwijnen. ${ }^{3}$

Op filmgebied tellen we sinds enige tijd de zegeningen van Mobile Movies. Het idee is simpel: je monteert een videoprojector en dvd-speler in je auto, kondigt je vertoningsplannen aan in je vriendenkring en verzamelt iedereen rond zonsondergang ergens op een donkere parkeerplaats met een grote muur. Ziedaar: uw eigen, tijdelijke, drive-inbioscoop. Dit concept is volgens de begeleidende website van het bedrijf $\mathrm{MobMov}^{4}$ gebaseerd op een wereldwijde 'guerrilla-drive-inbeweging' klaarblijkelijk een beweging van mensen die hun afhankelijkheid van peperdure 'cinemaplexen' meer dan zat zijn. De site roept op massaal te gaan 'mobielbioscopen'.

Winkelen kan inmiddels ook overal, onvermijdelijk en toch onverwacht. Het Amerikaanse warenhuis Target opende in de winter van 2004 een drijvende Kerstwinkel op de Hudson River van New Jersey. ${ }^{5}$ Het Japanse kledingbedrijf Uniqlo verkoopt haar waren in her en der opduikende (en evensnel weer verdwijnende) schipcontainers. ${ }^{6}$ Dit soort eenvoudige doch functionele winkelcontainers wordt door designbedrijven als het Amerikaanse Lot-ek of het Singaporese Venue ontwikkeld om, volgens de ontwerpers, een doorbraak te bewerkstelligen van de grenzen tussen wonen, werken en spelen. Het bontst maakt het Japanse kledingmerk Commes Des Garçons het met haar 'guerrillawinkelconcept'. ${ }^{9}$ Van Berlijn tot Beirut en van Helsinki tot Den Haag, dit soort winkels is overal wel (even) te vinden. Het concept is doeltreffend: een lokale uitbater regelt een tijdelijke vergunning voor een leegstaand gebouw ergens in de binnenstad van een metropool, waarop Commes Des Garçons een gedeelte van haar restcollectie accessoires, parfums en mannen- en vrouwenkleren levert voor een beperkte periode; meestal slechts enkele weken. Rondom het merk en het guerrillathema worden allerlei publiciteitaantrekkende events georganiseerd: gala's, concerten en feestjes met Bekende Mensen (ofwel: met hen die voldoen aan het Paris Hilton-principe: mensen die bekend zijn vanwege het feit dat ze bekend zijn). Zodra de winkel verder trekt, keert het gebouw weer terug tot zijn voorheen verlaten staat.

Tot slot kunnen we nu ook bij mobiele hotels terecht - hotels die opduiken op plekken waar op dat moment behoefte is aan onderdak of publiciteit. Wat dat laatste betreft is het Stoli-Hotel een aardig voorbeeld..$^{10}$ Hierbij huurde wodkamerk Stolichnaya een aantal reclame- en pr-adviseurs in om hun sterke drank te vertalen in betekenisvolle ervaringen. Dat draaide uit op een reizend hotel, bestaande uit een receptie, verschillende bars, een 'spa', lounges gedecoreerd met het oog op de verschillende smaakjes van het merk, en dat alles inclusief volwaardige hotelka- 
mers. Het hotel wordt, daar waar het is gepland, in een mum van tijd opgericht en afgebroken in een verlaten kantoorgebouw of pakhuis. Zo was er een Stoli Hotel in Hollywood gedurende de maand oktober van 2007 - inderdaad compleet met Paris Hilton - en dook het reizende marketingcircus een maand later op in Chicago. ${ }^{11}$

Er zijn ook minder blatante tijdelijke hotelervaringen, zoals in het Spaanse Hotel Movil. ${ }^{12}$ Dit hotel is gevestigd op een trekker met oplegger en bestaat uit elf kamers, compleet met douche, toilet, plasmatelevisie en internet. Het vehikel kan op bestelling voorrijden en transformeert zich binnen dertig minuten tot een volwaardig hotel voor maximaal veertig mensen. Een ander voorbeeld is het Nederlandse 'instant hotel' Qbic, sinds november 2006 gevestigd in Amsterdam, Antwerpen en Maastricht. ${ }^{13}$ De kern van dit hotelconcept is dat een kamer of zogenaamde 'Cubi' niet groter is dan zeven kubieke meter, waarin zowel een handgemaakt Zweeds bed, een bureau, een flatscreen-tv, dvd-speler, badkamer, draadloze internetverbinding als een stemmige belichting passen. De gast doet verder alles zélf: van boeken en in- of uitchecken tot eten, drinken, tampons of USB-geheugensticks uit de muur trekken. De hele kubus wordt panklaar in China gemaakt, en zo kan een Qbic-hotel supersnel waar dan ook worden neergezet. Volgens het begeleidende persbericht richt dit hotel zich op een nieuwe generatie reizigers die een 'mobiel leven' leidt. De hotelbedenkers opperen dat in zo'n leven de grens tussen werk en privé vervalt.

\section{Waarheidsverdriet}

$\mathrm{Al}$ dit soort commerciële vindingrijkheid is prima te lezen door de bril van morele verontwaardiging. Te denken valt aan de schaamteloze toe-eigening van stedelijke verloedering in de vorm van hotels en winkels in leegstaande gebouwen, aan de principes van asymmetrische oorlogsvoering door het bewuste gebruik van 'guerrilla'-terminologie en aan de excessen van de westerse commerciële cultuur, met nauwelijks verhulde verwijzingen naar bootvluchtelingen, krakers en vrijheidsstrijders die gebruikt worden als min of meer vergelijkbare voorbeelden van degenen die door de dominante cultuur worden gemarginaliseerd en uitgekotst. Kom, we doen er nog een schepje bovenop: de voornaamste aanjager van deze dominante, westerse ofwel onze cultuur is natuurlijk het kapitalisme, dat in reclame, marketing en public relations haar primaire exponent kent. Dat nu juist de reclame haar eigen afval opvoert als originele en uitermate trendy vorm van marketing is mis- 
schien wel het beste bewijs voor de centrale stelling van de Franse filosoof Jean Baudrillard dat we met $z$ 'n allen leven in een van massamedia en consumentisme doordrenkte 'hyperwerkelijkheid': een volstrekt betekenisloze leefomgeving waarin niets meer waar of origineel is. ${ }^{14}$

$\mathrm{Nu}$ kunnen we, eenmaal ingeslagen op deze uitzichtloze postmoderne weg van waarheidsverdriet, stapsgewijs via de films, videospellen en stripverhalen van The Matrix, de hersenloze eurohouse van 2 Unlimited, ${ }^{15}$ de nihilistische romans van de Amerikaanse schrijver Brett Easton Ellis, ${ }^{16}$ de inmiddels door de statistiek naar het land der fabelen verwezen 'zesjescultuur' van Jan Peter Balkenende ${ }^{17}$ en de mensonterende ellende van RTLs De Gouden Kooi vlotjes uitkomen bij een cultuurpessimistische lezing van de toestand in de wereld en de rol die media daarin spelen. Het duurt dan niet lang tot we uiteindelijk collectief belanden op het zwalkende ponton van de serieuze journalistiek, waarin sommigen verlossing vinden van de dagelijkse toevloed van trivia, maar waarvan de meesten in feite ook niets meer verwachten dan sensatie en commercie.

Voor dat soort deprimerende analyses bent $\mathrm{u}$ vandaag aan het verkeerde adres. Toch vormen de voorbeelden van de Kubik-clubs, de Mobile Movies, de guerrillawinkel van Commes Des Garçons of het Hotel Movil ook geen aanleiding tot het aanheffen van een lofzang op de verworvenheden van een gegoede burgerij. Aan de andere kant moeten we al dit commerciële succes evenmin toeschrijven aan het meer dan succesvolle 'einde van de geschiedenis' in de vorm van het westerse vrijemarktdenken en liberaal-democratische model, zoals de Japans-Amerikaanse politieke filosoof Francis Fukuyama ons nu al bijna twintig jaar lang wil laten geloven. Ook dat soort eindconclusies zult u mij niet horen trekken. Ik zie in deze voorbeelden daarentegen een aantal wezenlijke kenmerken van de huidige samenleving die onze aandacht vragen, zonder dat we bij voorbaat al moeten besluiten of dit alles nou 'goed' of 'slecht' voor onze maatschappij is.

In wat volgt heb ik mij laten informeren door drie bronnen: de visie van eigentijdse denkers en artiesten, de wijze woorden van eminente Leidse collega's welke ik de laatste maanden om raad en advies heb gevraagd en het onderzoek, onderwijs en beleid dat mijn collega's en ik van de PraktijkStudie en de masterspecialisatie Journalistiek en Nieuwe Media samen verrichten. ${ }^{18}$ 


\section{Kenmerken}

Terug naar de architectuur en beleving van het SoCo Cargo Experiment en de andere illustraties van eigentijds marktvernuft. De genoemde voorbeelden hebben, als extreme exponenten van commerciële cultuur, een aantal kenmerken gemeen. Ze zijn allereerst van tijdelijke aard. Deze vergankelijkheid is buitengewoon specifiek: het gaat om zorgvuldig geplande episodes. In feite ligt de verwachte meerwaarde van het avondje uit of de overnachting on wheels juist besloten in zijn kortstondige bestaan. Deze hunkering naar episodische, unieke maar daardoor niet minder diepgaande ervaringen zien we terug in de werkwijze van de media. De klassieke massamedia speelden in op een publiek dat zich voor lange tijd committeerde aan de karakters en verhaallijnen van series als Dallas, Eastenders of Goede Tijden Slechte Tijden. Een dergelijke duurzame investering van tijd en gevoelsleven is ondenkbaar voor moderne jonge volwassenen. Daarom heeft contemporain entertainment vaak niet alleen een heftig, maar vooral ook eenmalig karakter. Meestal gaat het slechts om één seizoen, één uitzending, één thema, dat daarna vanzelfsprekend wel op zoveel mogelijke manieren wordt uitgemolken. ${ }^{19}$

Een tweede kenmerk van de voorrijdende hotels, stapelbare clubs en doe-hetzelfbioscopen is de nadruk op een unieke beleving. De kwaliteit van deze ervaring wordt bepaald door het meemaken van een momentopname en een intense beleving van het hier en nu. Het is interessant dat deze ervaring niet panklaar aan de klant wordt aangeboden, zoals het geval is bij een zorgvuldig uitgekiende groepsreis van Arke, een perfect geprogrammeerde uitzending van De Mies Bouwman Show of, voor de wat jongeren onder ons, RTL Boulevard. Invloedrijke economen van het ervaringsdenken, zoals Jeremy Rifkin en Bernd Schmitt, stelden zich in de jaren negentig van de vorige eeuw al verrukt voor hoe prachtig het voor de markt zou zijn als mensen niet meer alleen spullen zouden kopen, maar in plaats daarvan tegen betaling ook bediend konden worden met... ervaringen. Het alleraardigste verschil tussen een ding - een tafel, een bloempot, een automobiel - en een ervaring als product is dat bij de aanschaf van het eerste de kopershandeling voorbij is, terwijl de aanschaf van het tweede telkens weer opnieuw gemaakt moet worden. Ofwel: de koper blijft kopen.

De ervaringen die bij de genoemde diensten horen zijn grotendeels afhankelijk van de inbreng, deelname en daarmee co-creatie van de consument. Als deelnemers aan de uitgaans- of winkelervaring worden wij niet alleen geacht te weten wanneer het tijdelijke event plaatsvindt, maar zijn we ook verantwoordelijk voor het scheppen van de noodzakelijke voorwaarden (zoals bij de mobiele bioscoop), 
voor het zelf effectief benutten en verzorgen van alle faciliteiten (zoals in het Qbic Hotel) en voor het 'viraal' verspreiden van nieuws en informatie over de gebeurtenis, opdat er daadwerkelijk publiek komt opdagen (zoals bij guerrillawinkels en de Kubik-clubs). ${ }^{20}$ In de media kennen we de consument als collega al geruime tijd. U kunt daarbij denken aan de ingezonden-brievenrubriek en de opiniepagina's van krant en tijdschrift, of aan vormen van sms-televisie, zoals het stemmen op je favoriete artiest bij Idols. Videospellenmakers stellen enthousiaste spelers veelal voor niets specifieke software ter beschikking, zodat zij zelf nieuwe versies van hun favoriete spel kunnen maken. Deze door klanten geproduceerde versies worden door de industrie 'mods' genoemd (een afkorting van 'modifications'). Vaak zijn dit soort door enthousiastelingen vervaardigde varianten gewilder dan het oorspronkelijke spel. Zoals bij het mateloos populaire CounterStrike, een door fans gratis geproduceerde mod van de game Half-Life.

Het collaboratieve karakter van de relatie tussen makers en gebruikers van marktervaringen komt nog dieper tot uitdrukking in het kenmerk van personalisering dat de genoemde voorbeelden gemeen hebben. Ook al gaat het hier om professioneel verzonnen en geproduceerde evenementen, in principe is het mogelijk en tot op zekere hoogte zelfs de bedoeling dat de klant zich de ervaring toeeigent door deze aan te passen naar eigen wens of behoefte. Aangezien dit van elke ervaringsdeelnemer verwacht wordt, is hier sprake van een massapersonalisering. Misschien herinnert $\mathrm{u}$ zich wel de memorabele scène in de Britse comedy Life of Brian (uit 1979) van het Monty Python-collectief, waarin Brian - in de film een tegenstribbelende verpersoonlijking van Jezus - zijn discipelen er wanhopig van probeert te overtuigen dat ze niet massaal achter hem hoeven aan te lopen maar juist voor zichzelf moeten denken. Amechtig schreeuwt hij het volk toe: 'You're all individuals!', waarop de mensen hem eenstemmig antwoorden: 'Yes, we are all individuals!'

Onze collectieve neiging om alles naar hartenlust te customiseren (waardoor we toch weer allemaal precies hetzelfde zijn), komt in de mediawereld misschien nog wel het mooiste tot uitdrukking in de ringtones van onze mobieltjes. Dit soort downloadbare beltonen zijn zo populair, dat het gezaghebbende Amerikaanse muziektijdschrift Billboard een speciale hitparade van 'Hot Ringtones' hanteert. ${ }^{21}$ Aardig gegeven daarbij is dat in december 2007 voor het eerst een wereldwijde daling in het aantal verkochte ringtones werd gerapporteerd. ${ }^{22}$ Een reden hiervoor? Er komen steeds meer mobiele telefoons op de markt waarbij je zélf je eigen ringtone kunt maken. Overigens maakten deze aanpasbare beltonen, net zoals smstekstberichtjes, geen deel uit van de oorspronkelijke bedrijfsplannen van mobiele 
telefoonmakers. ${ }^{23}$ Dit zijn voorbeelden van producttoepassingen die door gebruikers werden gepopulariseerd, maar die door de uitvinders nooit zo bedacht of bedoeld waren.

\section{Media en sociale context}

In het kort gaat het hier telkens om tijdelijke, geïndividualiseerde en co-creatieve ervaringen, die in de management- en marketingliteratuur gezien worden als de motor van de eigentijdse culturele wereldeconomie. Ervaringen van kortstondig en intens geluk, onttrokken aan en op onze meest private verlangens afgestemde of afstembare producten en diensten. Reclamemakers worden nogal eens verguisd vanwege het vermaledijde effect dat hun werk op onze samenleving zou hebben. Deze hardwerkende creatievelingen zetten daar over het algemeen tegenover dat zij geen verlangens scheppen, maar slechts verschillende antwoorden op al bestaande vragen bieden. ${ }^{24}$ In dit licht bezien is het zinvol om op zoek te gaan naar de sociale context waarbinnen deze ervaringen tot uitdrukking komen. De rol van de (nieuwe) media in deze context is er een als aanjagers en versnellers van al bestaande sociaal-culturele trends.

Denk bijvoorbeeld aan relaties en het huwelijk. We weten dat onder jongeren het hebben van losse seksuele contacten gewoner is dan een langdurige relatie, waarbij het 'veel voor elkaar voelen' voor de overgrote meerderheid van Nederlandse jongens en meisjes tussen de 12 en 25 jaar genoeg reden is om seks te hebben. ${ }^{25} \mathrm{U}$ zult het met me eens zijn dat dit een wat vluchtiger drijfveer is dan trouwen en kinderen krijgen. Sinds de jaren negentig worden er in Nederland meer huwelijken ontbonden dan gesloten. ${ }^{26}$ In Engeland vormen echtparen met kinderen sinds enkele jaren minder dan een derde van alle huishoudens. ${ }^{27}$ In de Verenigde Staten staat dat cijfer op iets minder dan een $\mathrm{kwart}^{28}$ en in Australië op ruim ééntiende. ${ }^{29}$ Veel buitengewoon populaire zelfhulpboeken adviseren niet zozeer hoe je je huwelijk of relatie kunt redden, maar zetten juist vraagtekens bij het idee van eeuwige trouw en bieden handige tips om van hem (of haar) af te komen. ${ }^{30}$ Het scherpste voorbeeld komt wel van het Amerikaanse advocatenkantoor Fetman, Garland \& Associates. Dit kantoor, dat uitsluitend uit vrouwelijke juristen bestaat, baarde in de lente van 2007 opzien met een grote billboard-advertentie in een populaire uitgaanswijk van Chicago met daarop foto's van een schaars geklede man en vrouw, en het onderschrift: 'Life's short. Get a divorce. ${ }^{31}$ 
Ik denk in dit verband ook aan arbeidsverhoudingen en werkgelegenheid. De Amerikaanse wetenschapper Richard Sennett laat in het prachtige boek The Corrosion of Character (uit 1998) zien dat zelfs de arbeiders die op dit moment een vast contract voor onbepaalde tijd inclusief pensioenregeling bezitten vaak het gevoel hebben dat dit hen elk moment ontnomen kan worden. Deze angst wordt gevoed door de retoriek van politici die het ontslag van werknemers steeds gemakkelijker willen maken en ons daarnaast opjagen om toch vooral mee te gaan in de vaart der volkeren van de wereldwijde kenniseconomie. Ondanks deze baanangst en onzekerheidsretoriek gaat het in ons land, net zoals in andere rijke westerse regio's, goed wat betreft werkgelegenheid. De meeste mensen werken. De contractuele context van al dat werk is echter een ander verhaal. Volgens cijfers van het Centraal Bureau voor de Statistiek ontstaan door de aantrekkende economie de laatste jaren extra banen die door werkgevers worden ingevuld met uitzendkrachten. De Verenigde Staten, Frankrijk, Nederland en Engeland voeren de wereldranglijst aan van landen met het grootste aandeel uitzendkrachten in de werkzame beroepsbevolking. ${ }^{32}$ Daarnaast werkt een snel groeiend aantal werknemers in freelance- of anderszins zelfstandig verband; in de journalistiek is dat bijvoorbeeld ongeveer éénderde van alle journalisten. Dit soort vormen van tijdelijk dienstverband maakt zo structureel deel uit van het werkleven van jongeren dat sociologen en politici al spreken van de generatie 'permatemp' of 'permalance'. ${ }^{33}$

Onder arbeiders in de mediawereld zijn contingente werkverbanden eerder regel dan uitzondering - een situatie waarvan ik in mijn onlangs verschenen boek Media Work (2007) de gevolgen uiteenzet aan de hand van meer dan vijfhonderd interviews met mediawerkers in de Verenigde Staten, Zuid-Afrika, Nieuw-Zeeland en Nederland. De International Labour Organization van de Verenigde Naties spreekt in dit verband in een rapport uit 2006 over de zorgwekkende toename van zogenoemd 'atypisch' werk in de media. ${ }^{34}$ Dat wil zeggen: werken zonder contract, zonder rechten, zonder uitzicht op de toekomst, zonder carrièreperspectief en zonder dat een werkgever direct verantwoordelijk gehouden kan worden voor investering in haar werknemers. Prangend gegeven hierbij is dat ondanks alle groei het aantal banen in de Nederlandse cultuursector - waartoe de media behoren de laatste jaren daalt. ${ }^{35}$

Als onderdeel van mijn voorbereiding op het hoogleraarschap sprak ik vorig jaar met een aantal eminente Leidse collega's. Over de veranderende omstandigheden op het gebied van huwelijk, relaties en arbeidsverhoudingen deelden mr. Clementine Breedveld-de Voogd van onze vakgroep Civiel Recht en prof.mr. Guus Heerma Van Voss van het Departement Publiekrecht hun expertise. Op het 
gebied van huwelijk en concubinaat stelde Clementine vast dat ons land op dit moment eigenlijk geen eigentijds samenlevingsrecht heeft. Als je niet wilt trouwen en als je je leven in die zin wat flexibeler wilt inrichten, leef je in juridische zin in een jungle waarin niets helder of fatsoenlijk geregeld is. Guus legt in zijn werk haarfijn de vinger op de zere plek van het aloude arbeidsrecht, waar het ondanks de grootscheepse veranderingen op de arbeidsmarkt nog steeds wachten is op een cultuuromslag in de centrale gedachte achter de bescherming van werknemers van 'ergens blijven' naar 'ergens komen'. Met andere woorden: voor degenen die regelmatig van partner of baan willen, of gedwongen worden te wisselen, ontbreken de noodzakelijke voorwaarden voor een goede levenskwaliteit en vertrouwen in de toekomst.

\section{Vloeibaar leven}

In deze beschouwing worden we telkens weer herinnerd aan ervaringen van tijdelijke, gepersonaliseerde en sterk individualistische aard. Ik laat daarmee zien dat dit niet alleen geinige marketingvoorbeelden zijn, maar dat deze kenmerken wezenlijk deel uitmaken van de manier waarop de meeste mensen tegenwoordig in alle facetten van het leven staan. Een dergelijk leven, zo stelt de Poolse denker Zygmunt Bauman, is een vloeibaar leven waarin niets meer duurzaam lijkt en alles voortdurend aan verandering onderhevig is. Sterker nog, de spelregels en de scheidsrechters van deze onrustige samenleving worden ook constant overhoop gegooid of zelfs afgeschaft. Het ontbreken van eigentijds arbeids- en samenlevingsrecht is voor mij een goed voorbeeld hiervan, net zoals de in toenemende mate onbeschermde context van arbeidsomstandigheden van mensen die in de mediawereld werken. Volgens Bauman leidt dit onvermijdelijk tot gevoelens van diepe onzekerheid die zelfs de mooiste geluksmomenten kunnen aantasten. ${ }^{36}$

De Duitse socioloog Ulrich Beck voegt hieraan toe dat we steeds meer gedwongen zijn om voor structurele onzekerheden en risico's uitsluitend biografische oplossingen te vinden. Er is niets of niemand meer die ons het hand boven het hoofd houdt. In feite worden mensen tegenwoordig aan alle kanten afgeraden om nog te bouwen dan wel te vertrouwen op de woorden en het werk van priesters, presidenten, professionals of... professoren. Zelfredzaamheid is het devies. Zoals Bauman scherp opmerkt, is de manier waarop individuele mensen hun individuele problemen definiëren en op individuele basis proberen op te lossen aan de hand van hun individuele vaardigheden en mogelijkheden de enige overgebleven 'publieke' zaak. 
Deze beklemmende werkelijkheid zien we dagelijks terug in de talloze programma's en genres op het gebied van de zogenoemde 'reality-televisie', waarvan het programma Big Brother ${ }^{37}$ wellicht het bekendste is. Hierbij ervaren we een realiteit waarin mensen zoals wijzelf rivaliserend met elkaar de meest alledaagse problemen het hoofd moeten bieden, waarin ze niet alleen uitsluitend op zichzelf zijn aangewezen, maar waaruit ze ook op elk moment door een onzichtbare buitenstaander zonder verdere opgaaf van redenen definitief verwijderd kunnen worden. Het is een werkelijkheid waarbij het voor elkaar opkomen of je uitsloven voor andere belangen dan die van jezelf averechts werkt, en waarvoor er geen andere wijsheid bestaat dan die je al bezit. Reality soaps zijn, in essentie, een zorgvuldig gestileerde weergave van het perfect particuliere en tegelijkertijd volmaakt vloeibare leven.

Ik ben fan van de cabaretier Theo Maassen (en niet alleen omdat ik ook in de wijk Woensel van Eindhoven heb gewoond). In zijn laatste show, Tegen beter weten in (uit 2006), maakt Maassen zich kwaad over het feit dat mensen geen moeite voor elkaar lijken te doen, maar in alles alleen nog maar voor zichzelf opkomen. Ik citeer: 'Moeite doen, daar gaat het over: moeite doen. Dát moet je mensen duidelijk maken, dat ze moeite moeten doen [...] Mensen doen zoveel moeite - maar alleen maar voor zichzelf en niet voor het grotere geheel waar ze deel van uitmaken. ${ }^{38}$ Maassen maakt een oprecht en belangrijk punt - maar het lijkt er in onze precaire en onzekere wereld op dat we alleen nog maar voor onszelf kúnnen opkomen. Hoe kunnen anderen dat dan mensen kwalijk nemen?

\section{Pessimisme}

In zijn recentste essaybundel vraagt de Duitse filosoof Jürgen Habermas aandacht voor de monumentale taak waarvoor de meeste mensen als individu in de hedendaagse 'post-nationale constellatie' staan, aangezien alle problemen waarmee zij zich geconfronteerd zien met geen mogelijkheid door het individu alleen kunnen worden opgelost. Verwoestende kapitaalvlucht, onvermijdelijke klimaatsverandering, opportunistische industrietrek van West naar Oost, wereldwijde migratie en een constante dreiging van grensoverschrijdend terrorisme... het zijn de meest voorkomende headlines in het dagelijkse nieuws, maar het zijn ook allemaal zaken die primair contingent zijn: het zijn stuk voor stuk onvoorzienbare noodsituaties waaraan je als individu niet of nauwelijks iets kunt doen of veranderen. Niet alleen dat: de traditionele sociale instituten waarop we normaliter terugvallen - zoals 
kerk, synagoge of moskee, de familie of de staat - zijn wat dit betreft eveneens impotent en bieden hooguit tijdelijk soelaas.

De Franse socioloog Pierre Bourdieu is een van de felste critici van deze maatschappelijke verschuiving van verantwoordelijkheden naar het individu zonder dat deze gewapend wordt om effectief het hoofd te kunnen bieden aan eigentijdse problemen en vraagstukken. Het moeten leven onder permanent precaire en constant contingente omstandigheden voorkomt dat mensen op een bewuste manier kunnen anticiperen op gevaren, aldus Bourdieu, en wat nog erger is: het maakt enige hoop op een toekomstige gezamenlijke actie tegen ondraaglijke leef- of werkomstandigheden nagenoeg ondenkbaar.

De Sloveense filosoof Slavoj Zizek gaat nog een stap verder. Deze waarschuwt nadrukkelijk tegen de veel te overspannen verwachtingen die we in dit verband van het individu hebben. De mens heeft nu eenmaal de neiging zich ergens aan vast te klampen, aldus Zizek, en dat kan in een situatie zonder de illusies van een geruststellend geloof, zorgzame overheid of vertrouwenwekkende autoriteit nogal eens ontaarden in ongebreideld narcisme, paranoïde gedrag, en het slaafs volgen van allerlei praatgrage populisten. We kunnen in Nederland daarbij denken aan de 'omdat je het waard bent'-reclames van het Franse cosmeticabedrijf L'Oreal, maar ook aan hijgerige opiniemedia als HP/De Tijd, en aan potsierlijke politici als Geert Wilders.

$\mathrm{Nu}$ is ondanks al mijn waarschuwingen en bedenkingen toch weer een soort cultuurpessimisme in dit verhaal geslopen. Opeens zijn we weer terug in de jaren zestig en zeilen we van het elitaire geweeklaag over de 'vertrossing' van de Nederlandse televisie naar de hooghartige wanhoopskretologie van Franse denkers als Guy Debord over de 'spektakelmaatschappij', waarin we met z'n allen machteloos overgeleverd zouden zijn aan het moraalloze marktdenken. Ik val weer even terug op Theo Maassen, daar waar hij terecht concludeert dat ondanks dit intimiderende primaat van de markt als ons eigen westerse fundamentalisme een pessimistische houding veel te gemakkelijk is, want 'pessimisme is een win-winsituatie: of je hebt gelijk, of het valt mee'. ${ }^{39}$ Daarom wil ik naast tijdelijkheid, individualisering en ervaringsdenken tot slot stilstaan bij het vierde kernelement van het huidige tijdsgewricht: co-creatie. 


\section{Convergentiecultuur}

Volgens Henry Jenkins, de directeur van de afdeling Vergelijkende Mediastudies van het Amerikaanse MIT en iemand met wie ik regelmatig mag samenwerken, is er in de wereld van mediamakers en -gebruikers de laatste tijd iets bijzonders aan de hand: hun rollen en functies lopen gaandeweg in elkaar over. Dit noemt Jenkins de uitkomst van een 'convergentiecultuur', waarmee hij doelt op het toenemende appel op de creativiteit van consumenten door producenten - en omgekeerd. We kunnen daarbij denken aan viral- ofwel buzz-marketing, waarbij van consumenten verwacht wordt dat zij elkaar via mobiele telefoon of e-mail op de hoogte stellen van nieuwe producten of diensten in plaats van dat dit gebeurt via dure tijdschriftadvertenties of televisiereclames. Ook kan je tegenwoordig bijna geen televisieprogramma meer zien zonder dat er een klemmend beroep op de kijker wordt gedaan om voor iets te stemmen of ergens op te reageren via sms, mms, email, chat of klik. In de journalistiek spreken verslaggevers, redacteuren, studenten en wetenschappers inmiddels met het grootste gemak over 'burgerjournalistiek', dat in de praktijk zoiets betekent als het uitbesteden van een gedeelte van het werk dat gesalarieerde journalisten gewoonlijk doen aan onbetaalde vrijwilligers uit het publiek. Jenkins suggereert dat de mediawereld eindelijk begrip en respect begint te krijgen voor het aloude fenomeen van de 'fan': hij of zij die louter voor de lol en met een pure passie zélf media maakt. ${ }^{40}$

Veel van ons gedrag op het gebied van nieuwe media wijst op het gelijk van Jenkins' analyse. We netwerken, communiceren, interacteren, zenden, ontvangen, chatten, mailen en linken dat het een lieve lust is. We doen aan van alles mee en worden overal (even) lid van. We schrijven ons in voor de chatrooms van TMF en de forums op Stand.nl, we starten een eigen weblog op de site van de Volkskrant of scheppen een avatar in de synthetische wereld van Second Life. We leggen met bloed, zweet en tranen een profiel aan op Hyves of regeren met ijzeren vuist over onze eigen clan in de virtuele wereld van World of Warcraft. Het is een gemeenschappelijk gekkenhuis, of een kakofonische collectieve intelligentie zo u wilt. Mijn Twentse collega-hoogleraar Jan van Dijk ziet in dit alles de contouren van een nieuwe netwerksamenleving, maar waarschuwt wel voor de digitale kloof die veel van dit soort pseudo-gezamenlijkheid kenmerkt. Ongeveer 20 procent van de wereldbevolking is online; in Nederland heeft 82 procent van de bevolking van 15 jaar en ouder toegang tot internet. ${ }^{41}$ Hoewel technologische toegang niet hetzelfde is als effectief gebruik, valt het op dat de meest bezochte websites bijna zonder uitzondering sociale functies hebben: zo staan Microsoft Network, MySpace, Face- 
book, Wikipedia, Hi5 en Orkut consequent in de wereldwijde top tien. ${ }^{42} \mathrm{Al}$ dit soort sites hebben met elkaar gemeen dat de meerwaarde van het gebruik ontstaat uit de interactie tussen de deelnemers. Volgens recente internationale studies en rapportages van het Sociaal en Cultureel Planbureau komen in de netwerken die mensen daar vormen vrienden, familie en collega's samen, waardoor diverse levensdomeinen door elkaar heen gaan lopen. ${ }^{43}$

Ik grijp even terug op mijn beschouwing van het vluchtige en onzekere karakter van liefdesrelaties en arbeidsverhoudingen in ons land. Wat ik daarbij naliet te vertellen, is dat verreweg de meeste mensen nog steeds een hecht familieleven hebben. Sterker nog: 'familie' wordt over het algemeen als een groot goed ervaren. Het punt is dat zo'n familie tegenwoordig een veel flexibeler betekenis heeft: het gaat om een dynamisch netwerk van zo nu en dan wisselende relaties en actoren, waarbij huwelijk of gezin geen noodzakelijke basisvoorwaarden meer zijn. In de precaire wereld van mediawerk zien we daarnaast dat arbeiders allerlei tactieken en strategieën ontwikkelen om samen het hoofd te bieden aan de permanente impermanentie van hun bestaan. Zo vormen producenten, regisseurs en cameramensen informele netwerken met acteurs, figuranten en setmedewerkers om elkaar werk toe te schuiven in de hectische wereld van film en televisie, organiseren jonge journalisten zich in bureaus of productiecollectieven, zodat ze hun bedrijfsrisico kunnen spreiden en ontstaan er online talloze forums en netwerken voor arbeiders om ervaringen uit te wisselen, nieuwe contacten op te doen en tijdelijke steun te vinden voor moeilijke tijden. Dat alles heeft weliswaar een veelal informeel en tijdelijk karakter, maar is tegelijkertijd een sterk voorbeeld van het sociale en collaboratieve karakter, dat de respons van mensen op toenemende veranderlijkheid, individualisering en fragmentatie kenmerkt.

De Spaanse socioloog Manuel Castells verheugt zich daarom over de opkomst van wat hij noemt een 'genetwerkt' individualisme. Hierdoor is het volgens Castells voor individuen toch mogelijk om van onderaf nieuwe en betekenisvolle vormen van gezelschap en gemeenschap op te bouwen. Castells en andere nieuwemediatheoretici als de Brit Scott Lash of de Franse futurist Pierre Lévy gaan daarbij wel iets te snel aan een wezenlijk aspect van al dit genetwerkte engagement voorbij, namelijk het kenmerk dat alle elektronische dan wel computergestuurde snufjes, handelingen en toepassingen met elkaar gemeen hebben: als het even niet bevalt, kunnen we zonder gevolgen pauzeren of ze uitzetten. Dit maakt al onze betrokkenheid bij datgene wat we met behulp van nieuwe media uitspoken weliswaar niet betekenisloos of asociaal, maar wel onvoorspelbaar en efemeer. 


\section{Journalistiek en nieuwe media}

Zo zijn we weer terug bij het tijdelijke, gepersonaliseerde, ervaringsrijke en cocreatieve karakter van ons avondje uit in de verbouwde schipcontainers van het SoCo Cargo Experiment. Voor mij komen hierin alle wezenlijke aspecten die het leven vandaag de dag bepalen bij elkaar. En dit is precies het punt van dit verhaal en van het onderzoek en onderwijs dat ik met deze leerstoel wil entameren: een beter begrip van hoe wij met z'n allen omgaan met onze nieuwe media, van de wijze waarop we iets proberen te begrijpen van de wereld om ons heen, en van de rol die de journalistiek in dit alles speelt. Dit begrip staat of valt met een holistische beschouwing van de maatschappelijke, culturele en technologische veranderingen in de samenleving die de journalistiek denkt te dienen. De journalistiek is, in termen van de Duitse filosoof Immanuel Kant, geen 'Ding an Sich' maar eerder een fenomeen. En daar gaat het in het onderzoek en de theorievorming over het vak regelmatig mis. Zowel journalisten als wetenschappers nemen het maar al te vaak voor lief dat er zoiets is als 'de' journalistiek en dat die journalistiek intrinsiek 'goed' en 'belangrijk' is. Daarom vervallen we telkens weer in oeverloze discussies over wie nu eigenlijk een 'echte' journalist is, terwijl het zowel filosofisch als praktisch gezien veel interessanter en relevanter is om iedereen als journalist te zien. Pas dan worden de mogelijkheden en idealen van het vak zichtbaar.

Door de journalistiek in theorie of praktijk niet te benoemen of haar veranderende plaats, functie en rol in de samenleving verder nauwelijks uit te werken krijgt het vak en het beroep iets onaantastbaars, iets wat buiten onze waarneming of ervaringswereld ligt. Het geeft het vak en de studie ervan iets exclusiefs, iets elitairs. De journalistiek als een beroep op zichzelf bestuderen of uitoefenen en daarover kritische, dan wel prijzende uitspraken doen, lijkt in dit verband een nogal fordistische exercitie. Daarmee doel ik op de telkens terugkerende, bloedeloos herkauwde en steeds weer dezelfde discussies in de vakliteratuur en de wetenschap over de invloed van de markt, over de verslaggeving rondom etnische minderheden, over de gevolgen van nieuwe media voor het wel en wee van al die arme maar hardwerkende journalisten. Het zal allemaal omgetwijfeld bijdragen aan mooie grachtengordeldebatten, boekjes en vlugschriften, maar de wijsheid die het oplevert sluit niet of nauwelijks aan bij de 'straatwerkelijkheid' van het nieuws of bij de alledaagse praktijk binnen redactielokalen. Mijn favoriete Nederlandse schrijver, Godfried Bomans, sprak ooit de wijze woorden: 'De beschrijving ener historische ontwikkeling zonder het heden als resultante is kathederwijsheid. ${ }^{\text {44 }}$ De journalistiek onderwijzen en onderzoeken als een ding op zich zonder te be- 
studeren hoe elke Nederlander een bijdrage kan leveren aan de controle op de macht, dient het beroep als commercieel bedrijf dat de aandacht van haar publiek aan adverteerders verkoopt - niet het vak als een idee of ideaal dat bijdraagt aan een gezondere democratie.

Rest mij in deze oratie nog uit te leggen wat tijdelijke, intense, gepersonaliseerde maar ook co-creatieve ervaringen in hemelsnaam te maken hebben met journalistiek. Gelukkig is dat de eenvoudigste opdracht van de eervolle functie die ik aan de Universiteit Leiden mag bekleden. Voordat ik die conclusies trek, hoop ik dat we het snel eens kunnen worden over wat de rol en invloed van nieuwe media is op dit alles. Wat we ook zien, ervaren of meemaken met nieuwe media, we moeten nooit vergeten dat al die de hardware en software en de dingen die we daarmee doen niet 'goede' of 'slechte' effecten op ons hebben. Nieuwe media hebben een aanjagende werking, versnellen wat er al is. Door te bestuderen welke vlammen er al branden, kunnen we weten welk vuur door de nieuwe media wordt aangewakkerd. Met dit uitgangspunt ga ik ten slotte terug naar journalistiek in de context van de kernelementen van het contemporaine tijdsgewricht.

Van de vergankelijkheid van vloeibaar modern engagement kan de journalistiek leren dat haar publiek niet meer gezien moet worden als min of meer kenbaar en daarmee als statisch. De lezer, kijker, luisteraar of surfer van vandaag is een andere dan die van morgen, ook al gaat het om dezelfde persoon.

Uit de hedendaagse hyper-individualisering kan de journalistiek opmaken dat de massa van eenlingen niet meer neutraal staat ten opzichte van de aangeboden informatie, maar er juist actief en co-creatief mee aan de slag gaat. Dat resulteert in een wervelwind van visies en opinies, zeker, maar daarmee ook in toenemende mogelijkheden tot het horen en insluiten van opvattingen en denkbeelden van hen, die anders buiten het spel van de dominante cultuur staan.

Uit de praktijk van co-creatie tussen maker en gebruiker leert de journalistiek dat het in haar queeste naar het geheim van de verborgen waarheid niet alleen staat. Mensen kunnen en willen meewerken, ongeacht of het professionele of amateur-journalisten zijn. Het samen nieuws maken en verspreiden is wellicht de vervolmaking van het beschavingsideaal van de actieve burger, ook al is deze betrokkenheid van tijdelijke aard.

Ten slotte moet onze ervaringseconomie een teken aan de wand voor de journalistiek zijn, aangezien het journalistieke verhaal niet (meer) stopt bij het ter perse gaan van de krant wanneer de site live gaat of als de uitzending begint. Nieuws biedt eindeloze mogelijkheden tot gesprek, tot uitwisselen van perspectieven en emoties, en dit is nu precies datgene waaraan de meeste behoefte lijkt te bestaan 
en waarvoor de intrinsiek interactieve internettechnologie zich bij uitstek leent. De journalist als deelnemer aan het gesprek dat de samenleving met zichzelf heeft, is de logische uitkomst en invulling van de kenmerken van het huidige tijdsbeeld. Wat wij met ons onderzoek en onderwijs bij Journalistiek en Nieuwe Media doen, is aan die rol van deelnemer concrete en inspirerende invulling geven, want we verwachten meer van de journalist (én van de burgerjournalist) dan uitsluitend deelname. Daar ligt de uitdaging voor de nieuwe journalistiek: het vervullen van verschillende functies tegelijkertijd, verspreid en versnipperd over diverse media, autonoom werkend en tegelijkertijd collectief opererend in dienst van het publiek dat geen publiek meer is. Het zijn inderdaad mooie tijden voor het vak én voor de wetenschap.

Ik heb gezegd. 


\section{Noten en Hyperlinks}

1. http://www.springwise.com/food_beverage/popup_nightclubs.

2. http://www.kubikbarcelona.com.

3. De Kubik ontwerpers maken zich op hun website sterk voor het gegeven, dat hun creaties 'Momente, Atmosphären \& Emotionen' vertegenwoordigen.

4. http://mobmov.org/manifesto.

5. http://www.chillibreeze.com/articles/Pop-upretailing.asp.

6. http://www.uniqlo.com/us/news/2006/o8/uniqlo_container_stores_arrive.html.

7. http://www.lot-ek.com.

8. http://www.venue.com.sg.

9. http://www.guerrilla-store.com/flash.php.

10. http://www.stolihotel.com.

11. http://lastheplace.com/2007/05/06/the-hotel-that-vodka-built-the-stoli-hotel-hits-hollywood.

12. http://www.hotelmovil.com.

13. http://www.qbichotels.com.

14. Het boek waar deze theorie door Baudrillard voor het eerst besproken wordt, Simulacra and Simulations uit 1981, was een inspiratiebron voor de filmserie The Matrix, waarin een in strak pak gekleed Jezusfiguur voor ons uit probeert te maken of de wereld waarin we leven echt of nep is. Om Baudrillard goed te begrijpen is het belangrijk om te weten dat hij de films maar niets vond, aangezien de kern van zijn filosofie daaruit bestaat dat een onderscheid proberen te maken tussen waarheid en leugen volstrekt zinloos is (zie: http://www.empyree.org/divers/Matrix-Baudrillard_english.html).

15. 2 Unlimited is de best-verkopende Nederlands-Belgische popact in de geschiedenis.

16. Zoals de aanklacht tegen de ongebreidelde consumptiecultuur American Psycho (1991), en mijn favoriet: Glamorama (1998) over fotomodellen als terroristen; zie: http://en. wikipedia.org/wiki/Bret_Easton_Ellis.

17. http://www.volkskrant.nl/binnenland/article474658.ece/Zesjescultuur_is_al_verleden_tijd.

18. Het volledige JNM team bestaat uit: Kees Boonman, Jos van den Broek, Peter Burger, Erik van Heeswijk, Jaap de Jong, Thea de Jong, Janine van Kempen, Willem Koetsenruijter, Els Lansdorp, Addie de Moor, Michiel van Opstal, Alexander Pleijter, Rob Punselie, Lilianne Ras, en Willem van Rooijen.

19. Het alternatief is de schepping van wat in goed Nederlands een franchise genoemd wordt: het beste voorbeeld daarvan is het merk Star Wars van de Amerikaanse producent George Lucas. Zijn aanpak is even simpel als doeltreffend: neem één verhaallijn en kopieer deze naar zoveel mogelijk producten, formats en ervaringen. Zelfs de fan-fictie (de Star Wars verhalen die niet door professionals maar juist alleen door fans gemaakt worden) mag van Lucas alle elementen uit zijn door auteursrecht beschermde films hergebruiken - maar dit op voorwaarde dat de originele verhaallijn intact blijft. Zo zijn 
er Star Wars films, cartoonseries, stripverhalen, novelles, bord- en computerspellen, kleding, speelgoed, en zelfs complete virtuele werelden. Allemaal uniek, allemaal hetzelfde.

20. De consument als collega van de producent is geen nieuw begrip. De Amerikaanse managementprofessor Eric von Hippel heeft bijvoorbeeld prachtig laten zien hoe vele voorname uitvindingen of baanbrekende patenten in de geschiedenis niet uit de koker van met winstoogmerk opererende bedrijven kwamen, maar juist door een gebruiker, klant of consument van een product werden geïntroduceerd.

21. http://www.billboard.com/bbcom/charts/chart_display.jsp?g=Singles\&f=Hot+Ringtones.

22. http://www.nytimes.com/2007/12/31/business/31ringtone.html?info=EXLINK.

23. http://www.firstmonday.org/issues/issue10_12/gopinath.

24. Het is een prachtige paradox: volgens de mensen die hun dagelijkse boterham verdienen met het beïnvloeden van ons koopgedrag regeren media niet, maar reageren ze slechts.

25. http://www.seksualiteit.nl/jongeren_367.html\#trend\%2oin\%2oseksuele\%2oattitudes.

26. http://www.nidi.knaw.nl/nl/atlas/nuptiality

27. http://www.statistics.gov.uk/downloads/theme_social/Social_Trends37/ST37_Cho2.pdf.

28. http://www.census.gov/prod/2004pubs/p20-553.pdf.

29. http://www.abs.gov.au/ausstats/abs@.nsf/7d12bof6763c78caca257061001cc588/ e6a9286119faoa85ca25699000255c89!OpenDocument\#.

30. Zelf-hulp boeken zijn op zichzelf een interessante casus in deze context, aangezien dit soort werk volgens Micki McGee (in Self Help, Inc.: Makeover Culture in American Life uit 2005) de nadruk legt op individuele beslissingsruimte en 'zelfmaakbaarheid' in plaats van investeren in en het vertrouwen op een sociaal netwerk of collectief.

31. http://abcnews.go.com/TheLaw/LegalCenter/story?id=3147979.

32. Volgens cijfers uit 2006 van het CIETT: http://www.ciett.org/index.php?id=55.

33. http://www.demos.org/pub558.cfm.

34. http://www.ifj.org/pdfs/ILOReporto70606.pdf.

35. http://www.cbs.nl/nl-NL/menu/themas/arbeid-sociale-zekerheid (zie 'Banen en vacatures naar bedrijfstak' onder het menu item 'Arbeidsmarkt in vogelvlucht'.

36. In de zomer van 2006 had ik de mogelijkheid professor Bauman te interviewen in zijn woning te Leeds. In dat gesprek zette hij zijn visie uiteen wat het voor mensen betekent om continue van moment tot moment te leven. De consequentie hiervan, aldus Bauman, is dat je nooit zeker kunt zijn hoe al die punten met elkaar samenhangen - zelfs niet als je achteraf op al je ervaringen terugkijkt. Sommige van die ervaringen zijn qua intensiteit vergelijkbaar met een soort 'Big Bangs', vergelijkbaar met de geboorte van ons universum. We weten een heleboel van wat er gebeurde in de fractie van een seconde na de 'Big Bang', maar weinig tot niets van daarvoor - we kunnen met andere woorden niet voorspellen wat er voor nodig is om de noodzakelijke bestanddelen voor een 'Big Bang' als beginpunt van de kosmos te bepalen. Deze fundamentele onzekerheid is volgens Bauman te vergelijken met het hedendaagse leven. Elk moment in tijd 
kan een 'Big Bang' voor ons zijn, kan in potentie de ultieme ervaring betekenen, een moment van hergeboorte - maar we kunnen er met geen mogelijkheid zeker van zijn dat dit inderdaad zal gebeuren. En zo leven we van eventuele 'Big Bang' naar 'Big Bang', zonder garanties, zonder te weten wat de voorwaarden zijn, zonder dat we daar op enige manier direct invloed op hebben.

37. Door Endemol in 1997 bedacht, in 1999 voor het eerst uitgezonden en daarna over de hele wereld overgenomen; zie: http://nl.wikipedia.org/wiki/Big_Brother_(televisieprogramma).

38. Citaat dvd van de voorstelling Tegen beter weten in (2006), als combinatie van uitspraken op 1:14:51 en 1:18:27.

39. Citaat dvd van de voorstelling Tegen beter weten in (2006), uitspraak op 1:22:00.

40. Nu zou ik daarbij willen opmerken, dat als ik me niet vergis dit altijd al de voornaamste motivatie is van iedereen die een carrière in de media ambieert. De vraag is dus eerder waarom werkgevers in de media die veronderstelde hartstocht nu opeens bij het publiek denken te moeten zoeken. Maar dit, vooralsnog, terzijde. Uit de mediastudies weten we overigens al langer dat de scheidslijn tussen producent en consument een illusie is. Volgens de Nederland-Indonesische mediatheoretica Ien Ang is de idee van een 'publiek' het verzinsel van mensen die het voor hun werk nodig hebben dat daar een intrinsieke behoefte aan is - het publiek is een bij elkaar gefantaseerde massa die je netjes kan uitdrukken in globale kijk- of lustercijfers. Dit voorkomt dat je je als producent hoeft te bekommeren over wie de mensen in dat 'publiek' nu eigenlijk zijn. Dezelfde imaginaire constructie werkt ook de andere kant op: we maken in de wetenschap veel te weinig expliciet wat we nu eigenlijk bedoelen als we het over 'de' journalistiek hebben.

41. Dat aandeel is 82 procent, tegenover bijvoorbeeld 19 procent gemiddeld wereldwijd; zie http://www.comscore.com/press/release.asp?press $=1885$ en http://www.internetworldstats.com/stats2.htm.

42. http://www.alexa.com/site/ds/top_50o.

43. http://www.scp.nl/publicaties/boeken/9789037702873/Nieuwe_links_in_het_gezin.pdf.

44. Uit de bundel Omnibus: humor en ernst uit het werk van Godfried Bomans (1962), p.198. 



\section{Bibliografie}

Baudrillard, Jean (1998 [1981]). Simulacra and simulations. In: Mark Poster (red.), Jean Baudrillard, selected writings. Palo Alto: Stanford University Press, pp.166-184

Bauman, Zygmunt (2000). Liquid modernity. Cambridge: Polity Press

Bauman, Zygmunt (2005). Liquid life. Cambridge: Polity Press

Beck, Ulrich (1992). Risk society: towards a new modernity. Londen: Sage

Bourdieu, Pierre (1998). Acts of resistance: against the new myths of our time. Cambridge: Polity Press

Castells, Manuel (2001). The internet galaxy. Oxford: Oxford University Press

Deuze, Mark (2007). Media work. Cambridge: Polity Press

Dijk, Jan van (2005). Network society: social aspects of new media. Tweede druk. Londen: Sage

Fukuyama, Francis (1992). End of history and the last man. New York: Free Press

Habermas, Jurgen (2001). The postnational constellation. Boston: MIT Press

International Labour Organization (2006). The changing nature of work: a global survey and case study of atypical work in the media industry. Research report. URL: http://www.ifj. org/pdfs/ILOReporto70606.pdf

Jenkins, Henry (2006). Convergence culture. New York: New York University Press

Lash, Scott (2002). Critique of information. Londen: Sage

Lévy, Pierre (1997). Collective intelligence: mankind's emerging world in cyberspace. New York: Perseus

Lévy, Pierre (2001). Cyberculture. Minneapolis: University of Minnesota Press

Rifkin, Jeremy (2001). The age of access. Marston Mills: Tarcher

Schmitt, Bernd (1999). Experiential marketing. New York: Free Press

Sennett, Richard (1998). The corrosion of character. New York: W.W. Norton \& Company

Twitchell, James (1996). Adcult USA. New York: Columbia University Press.

Wellman, Barry, Haythornthwaite, Caroline (red.) (2002). The Internet in everyday life. Malden: Blackwell

Zizek, Slavoj (1991). For they know not what they do: enjoyment as a political factor. New York: Verso 